\title{
Stability-indicating LC Method for Quantification of Azelnidipine: Synthesis and Characterization of Oxidative Degradation Product
}

\author{
Azelnidipin Miktar Tayini İçin Stabilite Göstergeli LC Yöntemi: Oksidatif \\ Bozunma Ürününün Sentezi ve Karakterizasyonu
}

\author{
(D) Sandeep S. SONAWANE*, (D) Pooja C. BANKAR, (D) Sanjay J. KSHIRSAGAR \\ MET's Institute of Pharmacy, MET League of Colleges, Bhujbal Knowledge City, Nashik, India
}

\begin{abstract}
Objectives: In the work presented here, the degradation behavior of azelnidipine under diverse forced degradation conditions was studied. A stability-indicating liquid chromatographic method was established which could separate and resolve azelnidipine from its degradation products. Further, chemical kinetics under acidic and alkaline conditions were studied, and validation studies were performed.

Materials and Methods: Using reversed-phase chromatography, azelnidipine and its formed degradants were resolved using phosphate buffer (pH 3.0) and methanol in a mixture of $10: 90 \% \mathrm{v} / \mathrm{v}$ as a mobile phase at a flow rate of $1.0 \mathrm{~mL} / \mathrm{min}$. All eluents were detected at a wavelength of $256 \mathrm{~nm}$. Results: Azelnidipine was degraded under acid, alkali, wet heat, and oxidized environment. The pH-dependent rate of hydrolysis of azelnidipine was studied under acidic and alkaline conditions and chemical kinetics were determined. Further, the oxidative degradation product of azelnidipine was synthesized and characterized as 3-(1-benzhydrylazetidin-3-yl) 5-isopropyl 2-amino-6-methyl-4-(3-nitrophenyl) pyridine-3,5-dicarboxylate (dehydro-AZD).

Conclusion: The susceptibility of azelnidipine to hydrolysis was attributed to the presence of ester at 3 and 5 positions of 1,4 dihydropyridine. Further, under oxidative conditions, the aromatization of 1,4 dihydropyrinine resulted in dehydro-AZD. Azelnidipine followed the first-order reaction under acid and alkali hydrolysis, and was more susceptible to degradation under acidic conditions. The synthesized and confirmed dehydro-AZD was found as one of the metabolites and impurities of azelnidipine. The evaluated validation parameters ascertained the practicality of the method for the quantification of azelnidipine tablets.
\end{abstract}

Key words: Azelnidipine, chemical kinetics, degradation product, HPLC, method validation, stability-indicating

ÖZ

Amaç: Bu çalışmada, azelnidipinin çeşitli zorlu bozunma koşulları altında bozunma davranışı incelenmiştir. Azelnidipinin stabilitesini gösteren, azelnidipini bozunma ürünlerinden ayırabilen ve çözebilen sıvı kromatografik yöntem geliștirilmiştir. Ayrıca asidik ve alkali koşullar altında kimyasal kinetikler incelendi ve doğrulama çalışmaları yapıldı.

Gereç ve Yöntemler: Azelnidipin ve oluşan bozunma ürünleri, mobil faz olarak kullanılan fosfat tamponu ( $\mathrm{pH} 3,0)$ ve metanol (\%10:90 h/h) ile, 1,0 $\mathrm{mL} / \mathrm{dk}$ akış hızında ters faz kromatografisi kullanılarak ayrıştırıldı. Tüm eluentler $256 \mathrm{~nm}$ dalga boyunda tespit edildi.

Bulgular: Azelnidipin asit, alkali, ıslak ısı ve oksitlenmiş ortam koșullarında degrade edildi. Azelnidipinin pH'ye bağlı hidroliz hızı asidik ve alkali koşullar altında çalışılmış ve kimyasal kinetik belirlenmiştir. Ayrıca, azelnidipinin oksidatif bozunma ürünü olan 3-(1-benzhidrilazetidin-3-il) 5-izopropil 2-amino-6-metil-4-(3-nitrofenil) piridin-3,5-dikarboksilat (dehidro-AZD) sentezlendi ve karakterize edildi.

Sonuç: Azelnidipinin hidrolize duyarlılığı, 1,4 dihidropiridinin 3 ve 5 pozisyonlarındaki esterin varlığı ile ilişkililendirildi. Ayrıca, oksidatif koşullar altında 1,4 dihidropirinin aromatizasyonu dehidro-AZD eldesi ile sonuçlandı. Azelnidipin için, asit ve alkali hidroliz altında bozunmasının birinci derece kinetiğe uyduğu belirlendi ve asidik koșullar altında bozunmaya daha duyarlıydı. Sentezlenen ve doğrulanan dehidro-AZD, azelnidipinin 
metabolitlerinden ve safsızlıklarından biri olarak bulundu. Değerlendirilen doğrulama parametreleri, azelnidipin tabletlerinin miktar tayini için yöntemin pratikliğini belirlemiştir.

Anahtar kelimeler: Azelnidipin, kimyasal kinetik, bozunma ürünü, HPLC, metot validasyonu, stabilite göstergesi

\section{INTRODUCTION}

Stability experiments aim to recognize the likely alterations with drug substances and products with regards to time under various storage conditions. It is anticipated that all the analytical methods used during the study should be stabilityindicating. Although any method evaluating changes in the physico-chemical properties of a drug substance or product should indicate stability, chromatographic methods are the most common stability-indicating methods (SIM). ${ }^{1}$ A major challenge in SIM development is the generation of stability test samples which are the real-time samples and contain all degradation products which may form under normal storage conditions. For stability evaluation, forced degradation experiments are conducted where the drug substances and products are heated to elevated temperatures under different $\mathrm{pH}$ conditions at different intervals, oxidation, dry heat, and photolytic conditions.

Chemically, AZD (Figure 1) is ( \pm ) 3-(1-benzhydrylazetidin3-yl) 5-isopropyl 2-amino-6-methyl-4-(3-nitrophenyl) -1,4-dihydropyridine (DPH)-3,5-dicarboxylate. ${ }^{2}$ AZD is official in Indian Pharmacopoeia $2014^{3}$ and Japanese Pharmacopoeia $2016 .^{4}$

AZD is a third-generation calcium channel antagonist and an effective antihypertensive agent used in patients suffering from hypertension. ${ }^{5}$ It specifically suppresses the L-type calcium channels of smooth muscle cells, and prevents the influx of transmembrane calcium. ${ }^{6}$

A literature review found numerous analytical methods stated for the estimation of AZD, including AZD estimation in pharmaceutical formulations by high performance liquid chromatography (HPLC), ${ }^{7-10}$ ultraviolet (UV) spectroscopy ${ }^{11}$ in biological fluids by hyphenated LC-mass spectrometry (MS) techniques, ${ }^{12,13}$ enantiomeric separation and estimation of AZD by HPLC ${ }^{14}$ and LC-tandem MS..$^{15}$ Along with these, an extensive literature exists on SIM for the estimation of AZD, including HPLC ${ }^{16,17}$ and HPTLC. ${ }^{18}$ Two SIM have been reported for the

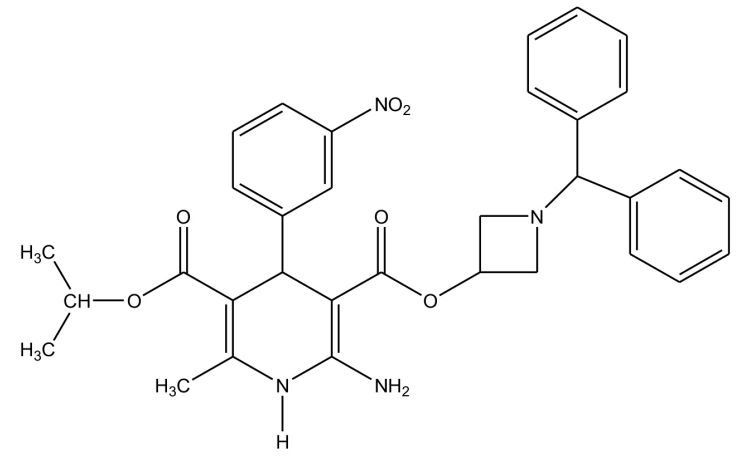

Figure 1. Chemical Structure of AZD simultaneous estimation of AZD and olmesartan.19,20 Further, the degradation of AZD under radical initiator-based oxidative conditions was studied. ${ }^{21}$

Moreover, limited shreds of evidence have been reported regarding the degradation behavior of AZD under different degradation conditions as well as no chemical kinetic study has been performed to date.

To address these unaccounted phenomena, the objectives of the current investigation was to ascertain an LC approach for AZD quantification in bulk and tablets which could separate and resolve the AZD from its degradants, to validate the method to prove the accuracy, precision, robustness, and stabilityindicating power of the method. The study was set out to explore the degradation behavior of AZD under different forced degradation conditions and to study the kinetics under acidic and alkaline conditions.

Further, from the literature, it was revealed that 3-(1-benzhydrylazetidin-3-yl) 5-isopropyl 2-amino-6-methyl4-(3-nitrophenyl) pyridine-3,5-dicarboxylate (dehydro-AZD) is the oxidative degradation product of $A Z D{ }^{21}$ as well as one of the major AZD metabolites. ${ }^{22}$ According to the literature 1,4-DHP derivates oxidize in the liver by cytochrome P-450 into pyridine derivatives (aromatization of 1,4-DHP). ${ }^{23}$ This was of high interest and therefore, the study was continued to synthesize and interpret the oxidative degradation product of AZD.

\section{MATERIALS AND METHODS}

\section{Chemicals and reagents}

A pharmaceutical grade AZD (certified to contain $99.91 \% \mathrm{w} / \mathrm{w}$ on dried basis) was obtained from Precise Pharmaceuticals Ltd, Nashik, India as a gift sample. In the investigation, methanol was of HPLC grade and other chemicals were of Analytial Reagent grade. All chemicals were bought from SDFLC - SD Fine Chem Ltd, Mumbai, India. The varying strengths of hydrochloric acid, sodium hydroxide, and hydrogen peroxide were prepared freshly by diluting appropriately with double distilled water, and were further used after filtering through membrane filter papers (Millipore India Pvt. Ltd., Bengaluru, India). The tablets containing AZD $16 \mathrm{mg}$ were bought from the residential market.

\section{Instrumentation and chromatographic conditions}

HPLC system used in the analyses consisted of binary pumps (PU 2080 plus), Jasco Corporation, Tokyo, Japan with 20 $\mu \mathrm{L}$ sample injector and multi-channel UV-visible detector, UV-2077, Jasco Corporation, Tokyo, Japan. All signals were recorded using Borwin software (version 1.50).

All chromatographic analyses were conducted on the $\mathrm{C} 18$ column with dimensions of $250 \times 4.6 \mathrm{~mm}, 5 \mu \mathrm{m}$ using a blend of 
$25 \mathrm{mM}$ phosphate buffer ( $\mathrm{pH} 3.0$ ), and methanol (10:90\% v/v) at a constant flow of $1.0 \mathrm{~mL} / \mathrm{min}$. The detector wavelength was set out at $256 \mathrm{~nm}$, which was the absorbance maxima of the AZD.

\section{Forced degradation studies}

Forced degradation trials were carried out on AZD bulk drug sample and on AZD tablets as per ICH Q2A (R1).24 Preliminary experiments were conducted to decide the strength of the stressor used, temperature of exposure, and time of heating. Under acidic and alkaline degradation, AZD was exposed to 0.1 $\mathrm{N} \mathrm{HCl}$ and $0.1 \mathrm{~N} \mathrm{NaOH}$ at $70^{\circ} \mathrm{C}$ for $35 \mathrm{~min}$, respectively. Wet heat degradation was achieved by refluxing the drug into double distilled water for $8 \mathrm{~h}$ at $70^{\circ} \mathrm{C}$. Further, AZD was exposed to $3 \%$ $\mathrm{v} / \mathrm{v}$ hydrogen peroxide under dark for $24 \mathrm{~h}$. The oxidized sample was heated on water bath to eliminate the leftover hydrogen peroxide. Degradation under dry heat condition occured by heating the AZD for $6 \mathrm{~h}$ in a hot air oven at $70^{\circ} \mathrm{C}$ and photolytic degradation by exposing the AZD under 7-day cycles to direct sunlight.

After exposure, degradation samples were collected and diluted suitably with the mobile phase. The obtained $10 \mu \mathrm{g} / \mathrm{mL}$ of samples were injected in the LC system. The decrease in the area under curve (AUC) of AZD compared to the standard AZD sample and with the appearance of secondary peaks in the chromatograms were noted as degradation. Appropriate counter blank samples were used to impede errors.

\section{Chemical kinetic studies}

To study the chemical kinetics of AZD under acidic and alkaline conditions, $10 \mathrm{mg}$ of AZD was transferred to two separate round bottom flasks, and in each flask, $10 \mathrm{~mL}$ of $0.1 \mathrm{~N} \mathrm{HCl}$ and $0.1 \mathrm{~N} \mathrm{NaOH}$ were added, respectively. The resulting solutions were heated in a thermostatic water bath at $50^{\circ} \mathrm{C}$ for $35 \mathrm{~min}$. After $5 \mathrm{~min}$ intervals, the appropriate quantity was quenched, diluted with the mobile phase to obtain $10 \mu \mathrm{g} / \mathrm{mL}$, and injected in the LC system.

\section{Synthesis and characterization of dehydro-AZD}

An accurately weighed $1 \mathrm{~g}$ quantity of AZD was transferred to a conical flask, to which $20 \mathrm{~mL}$ of acetonitrile was added and the solution was stirred for $10 \mathrm{~min}$. To it, $1 \mathrm{~g}$ of 2,3-dichloro5,6-dicyano-1,4-benzoquinon was added. The resulting mixture was again stirred for 20 min and was kept in dark at room temperature for $7 \mathrm{~h}$. The obtained reaction mixture was washed with double distilled water. The resulting product was characterized using MS.

Preparation of standard stock solution, calibration curve standards, and estimation of $A Z D$ in tablets

The standard stock solution of $1 \mathrm{mg} / \mathrm{mL}$ of AZD was prepared in methanol. The prepared standard stock solution was diluted appropriately with the mobile phase to obtain $10,20,30,40$, 50 , and $60 \mu \mathrm{g} / \mathrm{mL}$ of calibration curve standards and injected in triplicate. To obtain the calibration curve equation, the recorded AUC at each calibration standard was plotted against respective concentrations, and the regression coefficient $\left(r^{2}\right)$, $y$-axis intercept, and the slope of the line were determined.
To estimate the AZD in tablets, twenty tablets were weighed and ground to a fine powder. The amount equal to the total weight of one tablet was weighed and moved to a $100 \mathrm{~mL}$ volumetric flask. The mixture was sonicated for $10 \mathrm{~min}$ after the addition of $70 \mathrm{~mL}$ methanol and diluted further to $100 \mathrm{~mL}$ with methanol. The obtained solution was filtered, subsequently diluted to obtain $10 \mu \mathrm{g} / \mathrm{mL}$, and injected in triplicate. The corresponding concentrations and the \% label claim were calculated using the calibration curve equation.

\section{Method validation}

The developed method was validated as per the ICH Q2 R1 guidelines ${ }^{25}$ to evaluate the accuracy, precision, detection limit $(D L)$, quantitation limit $(Q L)$, robustness, and specificity.

Accuracy and precision were executed by spiking the standard sample of AZD in the tablet solution at $80 \%, 100 \%$, and $120 \%$ levels across the calibration range in triplicate for three successive days. The acceptable accuracy was established by the closeness of the \% amount recovered with the \% amount added and the precision with low relative standard deviation \% (RSD). Further, the obtained data of accuracy and precision were subjected to One-Way ANOVA to ascertain the intermediate precision of the method. DL and QL were determined as DL: (3.3 $\sigma / S)$ and QL: $(10 \sigma / S)$, where $\sigma: S D$ of AUC and $S$ is the slope of the calibration curve, respectively. Robustness of the method was verified by executing minor changes in the flow rate $( \pm 0.2$ $\mathrm{mL}), \%$ methanol $( \pm 10 \%)$ and the detection wavelength $( \pm 5 \mathrm{~nm})$ and the effects on the system of the AZD peak were observed. To prove the specificity of the method, absolute separation of AZD from its degradation products and the absence of the interfering peaks at the retention times of AZD were evaluated.

\section{Statistical analysis}

In the results and discussion section, the statistical analysis was discussed in chemical kinetics and method validation.

\section{RESULTS AND DISCUSSION}

\section{Optimization of the chromatographic conditions}

To obtain the adequate retention time of AZD with acceptable system suitability, different mobile phases were tried. Initially, water was tried as an aqueous phase along with acetonitrile and methanol. However, the splitting of the AZD peak suggests a buffer in the mobile phase. Good peak shape and acceptable system suitability parameters (theoretical plates: 8991, asymmetry: 1.10) were obtained when phosphate buffer at $\mathrm{pH}$ 3.0 was tried with methanol using Phenomenex Hyperclone ODS (C18) column $(250 \times 4.6 \mathrm{~mm}, 5 \mu \mathrm{m})$. The adequate retention time of AZD at $4.703 \pm 0.12 \mathrm{~min}$ was obtained when $25 \mathrm{mM}$ phosphate buffer was used with methanol in the ratio of $10: 90 \%$ $\mathrm{v} / \mathrm{v}$, respectively. All eluents were detected at $256 \mathrm{~nm}$ in an isocratic mode at the flow rate of $1 \mathrm{~mL} / \mathrm{min}$.

\section{Forced degradation studies}

Under acidic conditions, two degradation products were obtained, whereas, under alkaline conditions, wet heat, and oxidative conditions, one degradation product was obtained. 
Inconsiderable decrease in the peak area of AZD or appearance of secondary degradation products were detected in dry heat and photolytic conditions.

The degradation behavior of AZD under different forced degradation conditions is presented in Table 1 and the respective chromatograms are presented in Figure 2.

From the degradation behavior of AZD under different conditions, it was observed that AZD is more susceptible to degrade under acidic and alkaline conditions followed by oxidation and wet heat conditions.

\section{Chemical kinetics}

A gradual decrease in the peak area (Figure 3) confirmed that AZD follows the first-order reaction under acidic and alkaline conditions. The rate constant $(K)$, half-life $\left(t_{1 / 2}\right)$, and shelf-life $\left(t_{90}\right)$ were determined using the following equations, respectively.

$K=\frac{2.303}{t} \log \frac{C_{0}}{C}$

equation

$t_{1 / 2}=\frac{0.693}{K}$

equation (

$t_{90}=\frac{0.104}{K}$

equation

From Table 2, the $\mathrm{K}$ value was found to be higher under acidic condition than alkaline condition which concludes that the rate

Table 1. Forced degradation behavior of AZD

\begin{tabular}{llll}
$\begin{array}{l}\text { Degradation } \\
\text { condition }\end{array}$ & $\begin{array}{l}\text { Degradation } \\
\%\end{array}$ & $\begin{array}{l}\text { RT of a } \\
\text { drug (min) }\end{array}$ & $\begin{array}{l}\text { RT of degradation } \\
\text { products (min) }\end{array}$ \\
\hline Acid & 21.27 & 4.82 & $2.76,3.18$ \\
\hline Alkali & 17.88 & 4.57 & 2.85 \\
\hline Wet heat & 8.59 & 4.82 & 3.45 \\
\hline $\begin{array}{l}\text { Hydrogen peroxide } \\
\text { induced oxidation }\end{array}$ & 10.07 & 4.82 & $\begin{array}{l}2.21 \text { (peroxide } \\
\text { blank), 3.27 }\end{array}$ \\
\hline
\end{tabular}

RT: Room temperature

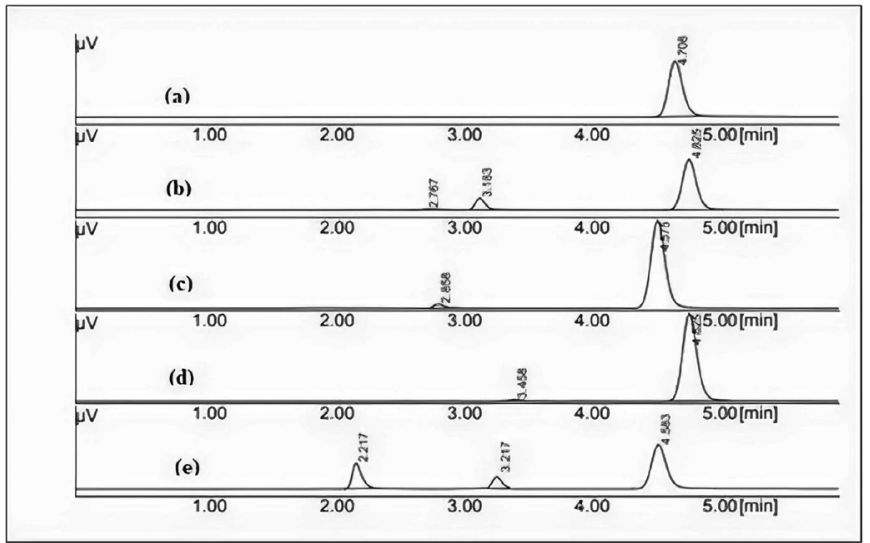

Figure 2. Representative chromatograms of AZD under (a) standard AZD (10 mg/mL), (b) acidic condition, (c) alkaline condition, (d) wet heat degradation (e) hydrogen peroxide induced oxidation of hydrolysis of AZD is higher in acid as compared to that in alkali. Also, the $t_{1 / 2}$ and $t_{90}$ values were the lowest for acid and highest for alkali. AZD contains two ester groups and a lactone ring; both groups are susceptible to hydrolysis. However, the rate of hydrolysis depends upon $\mathrm{pH}$, temperature, and substituents.

\section{Characterization of synthesized dehydro-AZD}

The MS of the synthesized compound is depicted in Figure 4 , where the major fragments identified had an $\mathrm{m} / \mathrm{z}$ ratio of 581.45 (molecular ion), 342.18, 238.14, and 167.11, respectively. The mass fragmentation pattern is depicted in Figure 5 , and it confirmed the synthesis of dehydro-AZD.

\section{Table 2. Summary of AZD acid and alkali hydrolysis kinetics}

\begin{tabular}{llll}
$\begin{array}{l}\text { Degradation } \\
\text { condition }\end{array}$ & $\mathrm{K}(1 / \mathrm{min})$ & $\mathrm{t}_{1 / 2}(\min )$ & $\mathrm{t}_{90}(\min )$ \\
\hline Acid degradation & $1.10 \times 10^{-2}$ & 63 & 9.45 \\
\hline Alkali degradation & $5.99 \times 10^{-3}$ & 115.69 & 17.36
\end{tabular}

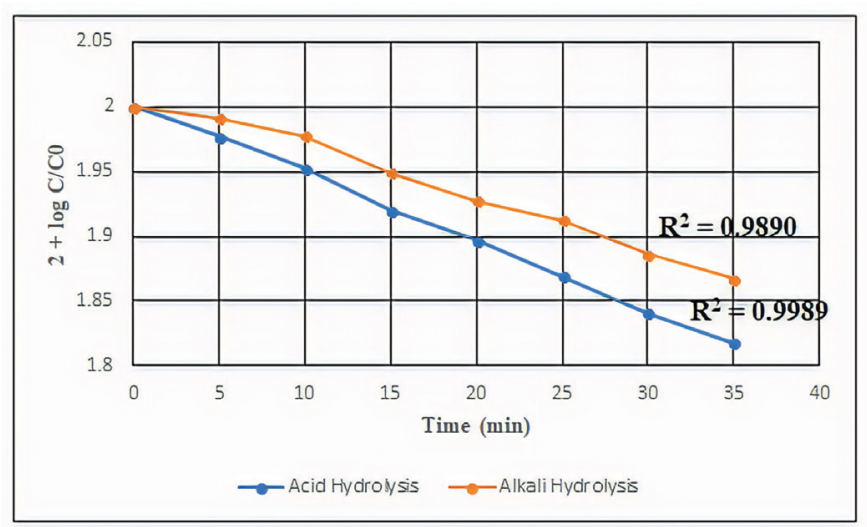

Figure 3. First-order plots of AZD under acidic and alkaline conditions

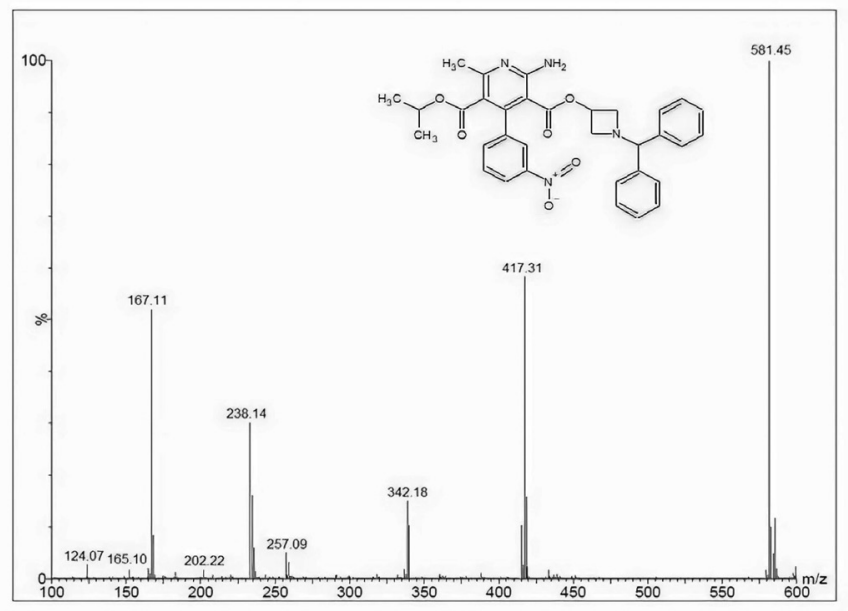

Figure 4. Mass spectrum of dehydro-AZD 


\section{Calibration curve and estimation of $A Z D$ in tablets}

AZD was found to be linear in the range of $10-60 \mu \mathrm{g} / \mathrm{mL}$ with $r^{2}: 0.9989$ with the calibration curve equation, $y: 53455 x+121119$.

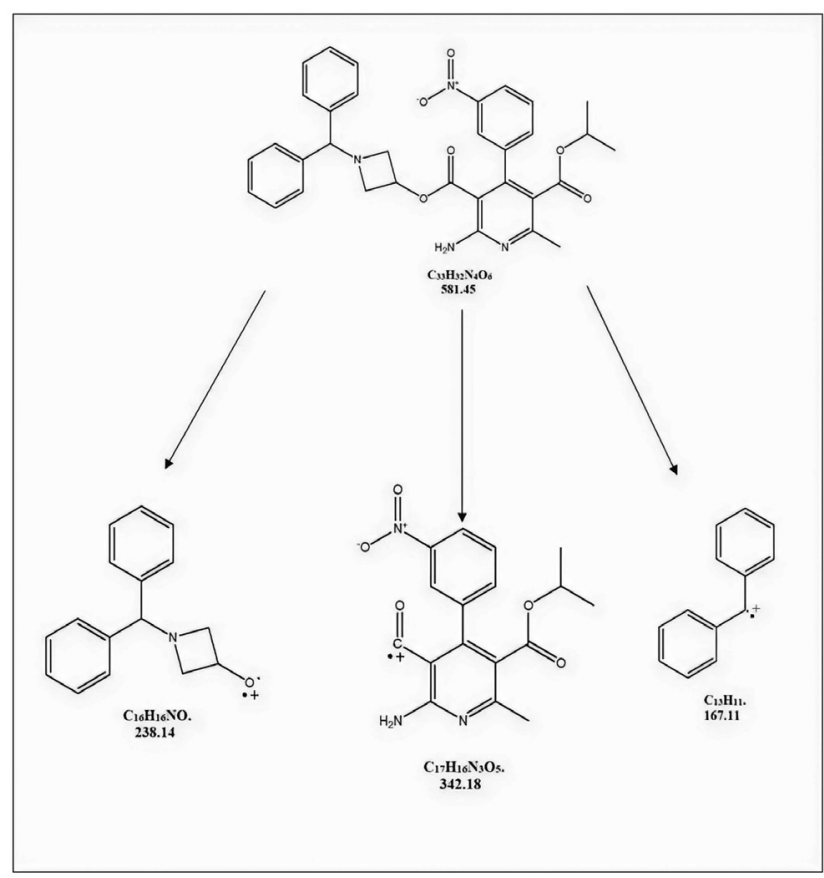

Figure 5. Fragmentation pattern of dehydro-AZD
The calibration curve is depicted in Figure 6. The analysis of the tablet showed $100.54 \pm 0.30$ of AZD.

\section{Method validation}

The results of accuracy and precision studies are presented in Table 3; mean concentration values were close to the spiked concentration of AZD, indicating good recovery. The precision was indicated by the low values of RSD \%. When the obtained data of accuracy and precision studies were subjected to ANOVA, the $F$ (observed) at each $Q C$ level was lower than the $F$ (theoretical) at $95 \%$ confidence interval, indicating insignificant

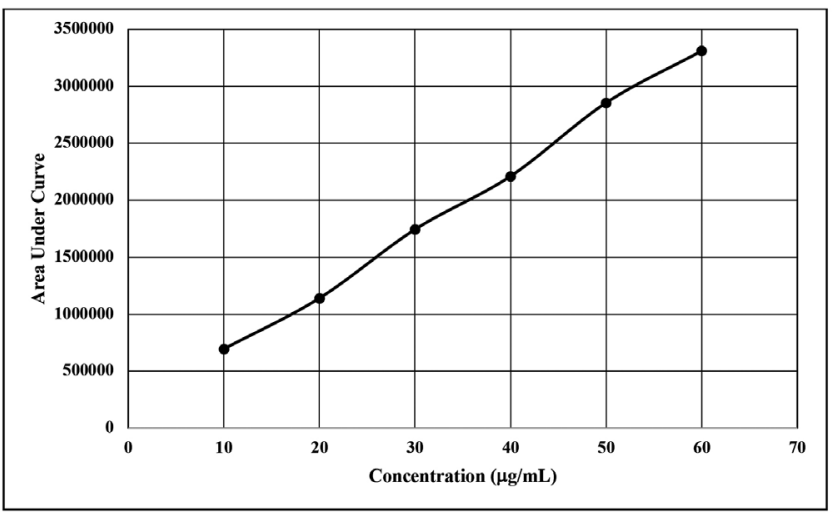

Figure 6. Calibration curve of AZD

\section{Table 3. Summary of accuracy and precision of AZD}

\begin{tabular}{|c|c|c|c|c|c|c|}
\hline \multirow[t]{2}{*}{ Amount added $(\mu \mathrm{g} / \mathrm{mL})$} & \multicolumn{3}{|c|}{ Amount found $(\mu \mathrm{g} / \mathrm{mL})$} & \multirow[t]{2}{*}{ Within mean square } & \multirow[t]{2}{*}{ Between mean square } & \multirow[t]{2}{*}{$\mathrm{F}$ value } \\
\hline & Day 1 & Day 2 & Day 3 & & & \\
\hline \multirow{3}{*}{$25+20=45(80 \%)$} & 44.78 & 44.52 & 44.51 & \multirow{6}{*}{0.0606} & \multirow{6}{*}{0.1541} & \multirow{6}{*}{2.5438} \\
\hline & 44.92 & 44.73 & 44.85 & & & \\
\hline & 44.92 & 44.02 & 44.49 & & & \\
\hline Mean & 44.87 & 44.42 & 44.62 & & & \\
\hline$\pm \mathrm{SD}$ & 0.08 & 0.36 & 0.20 & & & \\
\hline RSD \% & 0.18 & 0.82 & 0.45 & & & \\
\hline \multirow{3}{*}{$25+25=50(100 \%)$} & 49.33 & 49.12 & 49.15 & \multirow{7}{*}{0.0495} & \multirow{7}{*}{0.0825} & \multirow{7}{*}{1.6673} \\
\hline & 49.06 & 49.36 & 49.46 & & & \\
\hline & 49.14 & 49.15 & 49.82 & & & \\
\hline Mean & 49.18 & 49.21 & 49.48 & & & \\
\hline $\pm S D$ & 0.14 & 0.13 & 0.33 & & & \\
\hline RSD \% & 0.28 & 0.26 & 0.67 & & & \\
\hline \multirow{3}{*}{$25+30=55(120 \%)$} & 54.77 & 54.18 & 54.83 & & & \\
\hline & 54.69 & 55.37 & 54.80 & \multirow{5}{*}{0.2100} & \multirow{5}{*}{0.0546} & \multirow{5}{*}{0.2598} \\
\hline & 55.05 & 54.22 & 54.19 & & & \\
\hline Mean & 54.83 & 54.59 & 54.61 & & & \\
\hline$\pm \mathrm{SD}$ & 0.18 & 0.67 & 0.36 & & & \\
\hline RSD \% & 0.34 & 1.24 & 0.66 & & & \\
\hline
\end{tabular}

SD: Standard deviation, RSD: Relative standard deviation 
difference of the data of intra- and inter-day precision and proved the intermediate precision. The DL and QL were $0.43 \mu \mathrm{g} /$ $\mathrm{mL}$ and $1.32 \mu \mathrm{g} / \mathrm{mL}$, respectively. In the robustness experiment, no significant changes were observed in the system suitability parameters for AZD when minor changes were executed in the established chromatographic condition, demonstrating the robustness of the method. AZD was well separated and resolved from its degradation products; the absence of interfering peaks at the retention time of the AZD designated specificity.

\section{CONCLUSION}

The main conclusions of this work are drawn together and presented in this section:

- In the present work, LC method was stated for the estimation of AZD in bulk and tablets. The method proved to be simple and economic as the separation was achieved on a C18 column with the mixture of $25 \mathrm{mM}$ phosphate buffer $(\mathrm{pH}$ 3.0) and methanol as a mobile phase in the proportion of $10: 90 \% \mathrm{v} / \mathrm{v}$ in an isocratic mode, and all the formed degradation products along with AZD were separated out within less than 10 min of the run time.

- The method proved to be accurate with satisfactory precision. No significant alterations in the system suitability ascertained the robustness of the method. The acceptable specificity proved the stability-indicating nature of the method. The method was linear in the range of 10$60 \mu \mathrm{g} / \mathrm{mL}$ and the assay of the tablet was found to be $100.54 \% \pm 0.30 \%$ of the stated label of AZD.

- The forced degradation trials resulted in the degradation of AZD under acidic, alkaline, wet heat conditions, and peroxide-mediated oxidation.

- Hydrolysis is the major degradation pathway for drug substances with an ester functional group in their structure. The AZD has two ester groups present at 3 and 5 positions of the 1,4-DHP moiety, and hence, AZD may be susceptible to acid, alkali, and wet heat hydrolysis. Further, the $\mathrm{pH}-$ dependent rate of hydrolysis of AZD under acid and alkali conditions was determined by the chemical kinetic study, which proved the first-order reaction of AZD under acidic and alkaline conditions, respectively. The $t_{1 / 2}$ and $t_{90}$ values proved that AZD was more susceptible to degrade under an acidic enviornment than under an alkaline environment.

- Considering the atomization of 1,4-DHP to pyridine derivative under oxidative conditions, the oxidative degradation product of AZD was synthesized and confirmed using MS, which was found as one of the impurities and metabolites of AZD.

Conflict of interest: No conflict of interest was declared by the authors. The authors are solely responsible for the content and writing of this paper.

\section{REFERENCES}

1. Aubry AF, Tattersall P, Ruan Joan. Development of Stability Indicating Methods. In: Huynh-Ba K, ed. Handbook of Stability Testing in Pharmaceutical Development. New York: Springer Science and Business Media; 2009:139-161.

2. O'Neil MJ, ed. The Merck Index An Encyclopedia of Chemicals, Drugs, and Biological. 14th ed. New Jersy USA,: Merck research laboratories Division of Merck and Co. Inc.; 2006:153.

3. Indian Pharmacopoeia. Ghaziabad: Indian Pharmacopoeia. $7^{\text {th }}$ ed New Delhi: Indian Pharmacopeia Commission; 2014:1115.

4. The Japanese Pharmacopeia (English Version) [Internet]. The Ministry of Health, Labour and Welfare. 2016. Last Accessed Date: 03.11.2019. Available from: http://www.mhlw.go.jp/file/06-Seisakujouhou11120000-lyakushokuhinkyoku/JP17_REV_1.pdf

5. Chen BL, Zhang YZ, Luo JQ, Zhang W. Clinical use of azelnidipine in the treatment of hypertension in Chinese patients. Ther Clin Risk Manag. 2015;24:309-318

6. Catterall WA, Perez-Reyes E, Snutch TP, Striessnig J. International Union of Pharmacology. XLVIII. Nomenclature and structure-function relationships of voltage-gated calcium channels. Pharmacol Rev. 2005;57:411-425.

7. Hua-min A, Ju-cai W. Determination of content and related substances of azelnidipine by HPLC. West J Pharm Sci. 2006;21:581.

8. Pan YF, Zang JB, Ding J, Wang TM. Determination of azelnidipine tablets by HPLC. Qilu Pharm Aff. 2008:398-399.

9. Prabhakar D, Sreekanth J, Jayaveera KN. Method development and validatoin of azelnidipine by RP-HPLC. Int J ChemTech Res. 2018;11:7-12.

10. Gore MG, Dabhade PS. RP-HPLC method development and validation of azelnidipine. Int J Pharm Sci Res. 2016;7:5111.

11. Raskapur KD, Patel MM, Captain AD. UV-spectrophotometric method development and validation for determination of azelnidipine in pharmaceutical Dosage form. Int J Pharm Pharm Sci. 2012;4:238-240.

12. Gao Y, Li B, Zhu B, Liu D, Zhao H, Fang Z, Wang H, Lou H. A liquid chromatography-tandem mass spectrometric assay for the antihypertensive agent azelnidipine in human plasma with application to clinical pharmacokinetics studies; biomedical chromatography. Biomed Chromatogr. 2015;29:970-974.

13. Jian-Jun Z, Hong-Jian J, Xiao-Hua, Z, Yu-Bin Z, Hong-Wei F, Da-Wei X, Qin Hu. Determination of azelnidipine by LC-ESI-MS and its application to a pharmacokinetic study in healthy Chinese volunteers. Pharmazie. 2008;63:568-570.

14. Zhang K, Xue N, Li L, Li F, Du Y. Enantiomeric separation of azelnidipine by high performance liquid chromatography with chiral stationary phase. Chinese J Chromatogr. 2010;28:215-217.

15. Kawabata K, Samata N, Urasaki Y, Fukazawa I, Uchida N, Uchida E, Yasuhara $\mathrm{H}$. Enantioselective determination of azelnidipine in human plasma using liquid chromatography-tandem mass spectrometry. J Chromatogr B Anal Technol Biomed Life Sci. 2007;852:389-397.

16. Modi J, Patel SK, Parikh N, Shah SR, Pradhan PK, Upadhyay UM. Stability indicating analytical method development and validation for estimation of azelnidipine. World J Pharm Res. 2016;5:831-847. 
17. Rele RV, Sawant SA. Development and validation of stability indicating reverse phase liquid chromatographic method for the assay of azelnidipine in bulk and pharmaceutical formulations. Int J Pharma Biosci. 2016;7:376-380.

18. Rane AS, Mahajan SK. Validation and forced stability-indicating HPTLC method for determination of azelnidipine. World J Pharm Res. 2016;5:1053-1062.

19. Ganduri R, Peddapapireddigari J, Vurimindi H, Ramprakash. Stability indicating liquid chromatographic method for the simultaneous determination of olmesartan medoxomil and azelnidipine in combined tablet dosage form. Int J Pharma Sci Res. 2014;5:275-282.

20. Patel JK, Patel NK. Validated stability-indicating RP-HPLC method for the simultaneous determination of azelnidipine and olmesartan in their combined dosage form. Sci Pharm. 2014;82:541-554.

21. Ueyama E, Takahashi F, Ohashi J, Konse T, Kishi N, Kano K. Mechanistic study on degradation of azelnidipine solution under radical initiatorbased oxidative conditions. J Pharm Biomed Anal. 2012;61:277-283.
22. Kawabata K, Urasaki Y. Simultaneous determination of azelnidipine and two metabolites in human plasma using liquid chromatography-tandem mass spectrometry. J Chromatogr B Anal Technol Biomed Life Sci. 2006;844:45-452.

23. Guengerich FP, Sari MA, Brian WR, Iwasaki M, Bäärnhielm C, Berntsson P. Oxidation of Dihydropyridine Calcium Channel Blockers and Analogues by Human Liver Cytochrome P-450 IIIA4. J Med Chem. 1991;34:18381844.

24. ICH Guideline, Q1A (R2): Stability Testing of New Drug Substances and Products. Last Accessed Date: 17.12.2019. Available from: https:// database.ich.org/sites/default/files/Q1A\%28R2\%29\%20Guideline.pdf

25. ICH Guideline, Q2(R1): Validation of Analytical Procedures: Text and Methodology. Last Accessed Date: 12.01.2020. Available from: https:// database.ich.org/sites/default/files/Q2\%28R1\%29\%20Guideline.pdf 